\title{
Apriori Algorithm on Car Rental Analysis with The Most Popular Brands
}

\author{
Leo Fernando Panjaitan \\ STMIK Nusa Mandiri \\ Jakarta, Indonesia \\ nando.leo29@gmail.com
}

\author{
Yopi Handrianto \\ Universitas Bina Sarana Informatika \\ Jakarta, Indonesia \\ yopi.yph@bsi.ac.id
}

\author{
Achmad Nurhadi \\ Universitas Bina Sarana Informatika \\ Jakarta, Indonesia \\ achmad.ahh@bsi.ac.id
}

Submitted: Feb 26, 2020

Accepted: Mar 17, 2020

Published: Apr 1, 2020

\begin{abstract}
Nowadays, vehicle rental has become a common function for companies that have busy operational activities. Every company in carrying out operational activities requires a vehicle that is always there when needed. PT. Agung Solusi Trans is a vehicle rental company that rents various vehicle brands commonly used by customers to rent vehicles. In addition, PT. Agung Solusi Trans is also difficult to get updated information regarding the level of sales per period. Therefore, we need a decision support system and a method that can be used to design a business strategy that can provide an efficient and effective information, namely data mining using the a priori algorithm association method. The researcher specializes in taking only vehicle types as research material by selecting fifteen brands, including Agya, Yaris, Sienta, Calya, Avanza, Innova, Rush, Vios, Altis, Camry, Fortuner, Alphard, Hi Ace, Voxy, and Hilux. In analyzing the data, the writer uses a priori algorithm calculation by testing the hypothesis of two variables between the value of support and the value of confidence. After that, apriori algorithm is calculated using Tanagra. Based on the analysis done by the author, that the brands most sought after by customers are Calya, Avanza, Hilux. From these results can be used by PT. Agung Solusi Trans to prepare vehicle brands that are widely leased by customers and increase brand inventory.
\end{abstract}

Keywords - Apriori Algorithms, Analysis, Brands

\section{INTRODUCTION}

At this time the growth of business in the field of vehicle rental services is being looked after by people who have the need to overcome even odd numbers on the company's operational vehicles. With the existence of an even odd system created by the government, it is not surprising that many newcomer rental services have sprung up in the world of vehicle rental

One of the means of transportation that has a good function and with a lot of transport capacity, as well as easy and inexpensive to carry and rent is a car. In its development, the car rental business has become a very profitable business or business. Because at this time people are more pleased use the car to travel far and in the distance that is being traveled. For most people traveling by car will be more enjoyable and comfortable in the trip and can bring many family members, friends, or friends who take part in the trip. So that the pleasure in traveling will be easier to obtain when compared to using other means of transportation (Septavia et al., 2014).

Based on the above background, this study discusses data mining by classifying vehicle brands that are often rented by customers using a priori 
algorithm association rules to determine the pattern of item and itemset combination of vehicle rental sales data transactions at PT. Agung Solusi Trans for one year..

\section{LiteratURE REVIEW}

\section{A. Understanding Data Mining}

According to (Badrul, 2015) "Data mining is a technique which is a combination of methods of continuous data analysis with algorithms for processing large data.".

According to (Handrianto \& Farhan, 2019) "Data Mining is a process that uses statistical, mathematical, artificial intelligence and machine learning techniques to extract and identify useful information and related knowledge from various large databases".

According to (Irfiani, 2019), "Data mining is a method by extracting large amounts of information, in this way helping companies focus on important information in data warehouses".

According to (Anas, 2016), "Data mining algorithms mostly come from the form of developing algorithms in various fields of machine learning, statistics, artificial intelligence and artificial neural networks. Because it is not designed to handle data in very large sizes, while data mining in question is useful for handling data of such size, then one direction of research in the field of data mining is to develop these algorithms so that they can handle very large data sizes".

There are two reasons why data mining needs to be used, namely:

a. Finding patterns in the data can be disappointing for inexperienced decision makers due to the fact that potential patterns in the data are often invisible.

b. The amount of data is too large to manually analyze.

According to (Santoso et al., 2016), data mining has its own characteristics, among others:

a. Data mining must relate to the discovery of something that is hidden and has certain data patterns that were not previously known.

b. Data mining usually uses very large data

c. Data mining is used to make a critical decision, especially in determining a strategy. Based on some of the opinions mentioned above it can be concluded that data mining is the process of finding the results of large amounts of data stored in databases, data warehouses, sales data or other storage media. As a series of processes, data mining is divided into several process stages. These stages are interactive, the user is directly involved or through the mediation of a knowledge base (basic knowledge).

There are six data mining stages, including (Halimi et al., 2019) :

a. Data cleaning is the process of removing noise and inconsistent or irrelevant data.

b. Data Integration is the merging of data from various databases into one new database.

c. Data Selection is the data that is in the database is often not all used, therefore only the data that is suitable for analysis will be taken from the database.

d. Data transformation is data that is changed or merged into a format suitable for processing in data mining.

e. Mining process is the main process when the method is applied to find valuable and hidden knowledge from data.

f. Pattern Evaluation (Pattern Evaluation) is used to identify interesting patterns into the knowledge based found.

g. Knowledge presentation is the visualization and presentation of knowledge about the method used to obtain the knowledge obtained by the user.

\section{B. Definition of Association Rule}

According to (Kanti \& Indrajit, 2017) states that, "analysis of association rules in data mining is a data mining technique for finding association rules between a combination of items". The association rule analysis is known as one of the data mining techniques that is the basis of various other data mining techniques. The analysis phase of association rules will produce an efficient algorithm using high frequency patterns. This association rule aims to look for patterns that often occur among many transactions, where each transaction consists of several items.

According to Kusrini in (Listriani et al., 2016) stated that "The basic methodology of association analysis consists of two, namely: analysis of high frequency patterns and the formation of associative rules".

\section{a. High Frequency Pattern Analysis}

This stage looks for combinations of items that meet the minimum requirements of the support value in the database. The value of an item's support is obtained by the following formula. 


$$
\text { Support }(A)=\frac{\text { Total Transaction Containing A }}{\text { Total Transaction }} * 100 \%
$$

While the support values of the 2 items are obtained from the following formula 2 .

$\operatorname{Support}(\mathrm{A}, \mathrm{B}) \frac{\sum \text { Transaction Containing A and B }}{\sum \text { Transaction }} * 100 \%$

\section{b. Establishment of Associative Rules}

The formation of the association rules is done after all high frequency patterns have been found, then the association rules are found to meet the minimum requirements for confidence by calculating the associative rule confidence "if $\mathrm{A}$ then $\mathrm{B}$ ". The confidence value of the rule "if A then B" is obtained from the following formula:

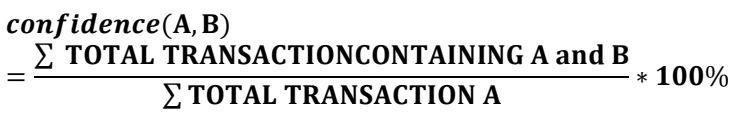

\section{Definition of Apriori Algorithm}

According to (Badrul, 2016), "Apriori algorithm is a basic algorithm proposed by Agrawal \& Srikant in 1994 to determine frequent itemsets as a rule of boolean association. A priori algorithm including the type of association rules in data mining".

Broadly speaking, the work of a priori algorithms is:

a. Formation of itemset candidates, k-itemset candidates are formed from a combination (k-1) itemset obtained from the previous iteration. One feature of the Apriori algorithm is the pruning of $\mathrm{k}$ itemset candidates whose subsets containing k-1 items are not included in the high frequency pattern with k-1 length.

b. Calculation of support for each k-itemset candidate. Support from each k-itemset candidate is obtained by scanning the database to count the number of transactions containing all items in the kitemset candidate. This is also a feature of the a priori algorithm which requires the calculation by scanning the entire database of the longest k-itemset.

c. Set high frequency pattern. High frequency patterns containing $\mathrm{k}$ items or $\mathrm{k}$-itemset are determined from candidate $\mathrm{k}$-itemset whose support is greater than the minimum support. If no new high frequency pattern is obtained, the whole process is stopped. If not, then $\mathrm{k}$ plus one and return to part 1.

\section{Definition of Tanagra}

According to (Badrul, 2016), "Tanagra is a free and useful data mining software for academic purposes and can be taken from several data mining methods in the form of data exploration analysis, statistical learning, machine learning and database areas". Tanagra software is said to be free, because the software is open source where every researcher can access to the source code, and add his own algorithm, as long as the researcher agrees and complies with the software distribution license.

\section{Proposed Method}

\section{A. Research Stages}

According to (Badrul, 2016), "Tanagra is a free and useful data mining software for academic purposes and can be taken from several data mining methods in the form of data exploration analysis, statistical learning, machine learning and database areas". Without the software is said to be free, because the software is open source where every researcher can access to the source code, and add his own algorithm, as long as the researcher agrees and complies with the software distribution license:

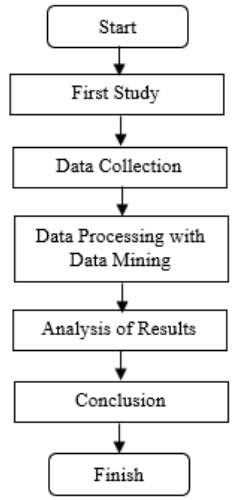

Source : Sikumbang (2018)

Figure 1. Research Stages

\section{B. Data Collection Methods, Population and Research Samples}

\section{Method of collecting data}

The research data collection was carried out in the following way:

\section{Observation or observation}

Observing information relating to the Apriori Algorithm Method at PT. Agung Solusi Trans. The results of direct observation are then recorded by the author so that it can be seen the application that can be done with the method.

\section{Interview}

The author conducted a direct interview with the marketing manager of PT. Agung Solusi Trans who knows product inventory data and vehicle rental sales 
transaction data that occurred in the company for a year.

\section{Literature Review}

Study the journal literature and reference books supporting the theory contained in the library.

\section{Study population and sample}

"Population is a generalization area in the form of subjects or objects studied and has certain qualities and characteristics determined by researchers to be studied, then conclusions are drawn ". (Sugiyono, 2015)

Whereas "The sample is part or acts as a representative of the population so that the results of research successfully obtained from the sample can be generalized to the population". (Sugiyono, 2015)

The population in this study is sales data seen from customers or customers who do all vehicle rental transactions at PT. Agung Solusi Trans. The object of the sample taken in this study, namely: vehicle rental data categorized by brand and month period in 2018. The sampling technique is a sampling technique. The technique used in this research is systematic nonprobability sampling where this sampling technique does not provide the same opportunity or opportunity for each population element selected to be sampled and taken based on the order of the population elements that have been given a sequence number.

Table 1. Vehicle Rental Data Samples

\begin{tabular}{|c|c|}
\hline Month & Item set \\
\hline 1 & Rush, Avanza, Hilux \\
\hline 2 & Innova, Avanza, Rush \\
\hline 3 & Vios, Camry, Innova \\
\hline 4 & Hilux, Innova, Avanza \\
\hline 5 & Avanza, Vios, Calya \\
\hline 6 & Avanza, Vios, Innova \\
\hline 7 & Alphard, Rush, Vios \\
\hline 8 & Avanza, Voxy, Sienta \\
\hline 9 & Innova, Hi Ace, Rush \\
\hline 10 & Innova, Fortuner, Yaris \\
\hline 11 & Avanza, Altis, Camry \\
\hline 12 & Avanza, Alphard, Calya \\
\hline
\end{tabular}

Source: Research Results (2019)

\section{Data Analysis Method}

The study was conducted on the selection of vehicle brands that are most interested in customers with the acquisition of vehicle rental data collection at PT. Agung Solusi Trans. In analyzing the data, the writer uses a priori algorithm calculation by testing the hypothesis of two variables between the value of support and the value of confidence. After that, a priori algorithm is calculated using Tanagra which functions as a matching of the results obtained in the previous calculation.

\section{Apriori Algorithm Calculation}

\section{A. High Frequency Pattern Analysis}

At this stage, the writer looks for a combination of items that meet the minimum requirements of the support value in the database. The value of an item's support is obtained by the following formula:

$$
\text { Support }(A)=\frac{\text { Total Transaction Containing A }}{\text { Total Transaction }} * 100 \%
$$

While the support value of 2 items is obtained from the following formula:

Support $(\mathrm{A}, \mathrm{B})=\mathrm{P}(\mathrm{A} \cap \mathrm{B})$

$$
\operatorname{Support}(\mathrm{A}, \mathrm{B}) \frac{\sum \text { Transaction Containing A and B }}{\sum \text { Transaction }} * \mathbf{1 0 0} \%
$$

And for the support value of 3 items obtained from the following formula:

$$
\operatorname{Support}(\mathrm{A}, \mathrm{B}, \mathrm{C}) \frac{\sum \text { Transaction Containing A,B dan C }}{\sum \text { Transaction }} * 100 \%
$$

\section{B. Formation of Association Rules}

After all high frequency patterns have been found and the iteration has stopped, then the association rules are found to meet the minimum requirements for confidence by calculating the confidence of associative rules. $\mathrm{A} \rightarrow \mathrm{B}$.

The confidence value of the rules $\mathrm{A} \rightarrow \mathrm{B}$ is obtained from the following formula :

confidence $(A, B)=\frac{\sum \text { Total Transaction Containing A and B }}{\sum \text { TOTAL TRANSACTION A }} * 100 \%$

\section{Apriori Algorithm Calculation with Tanagra}

Apriori algorithm on Tanagra can be formed with predetermined steps. The steps in forming the algorithm are as follows:

\section{A. Support Algorithm}

In determining the support algorithm there are inputs, outputs and processes. The following are the results of input, output and data processing: 


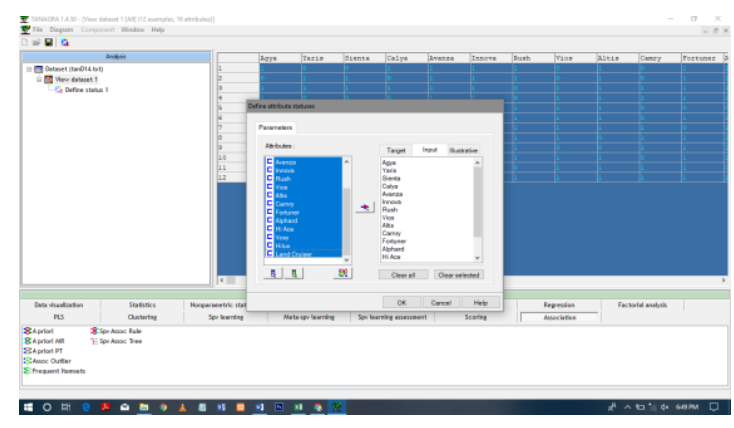

Figure 2. Data Input Results

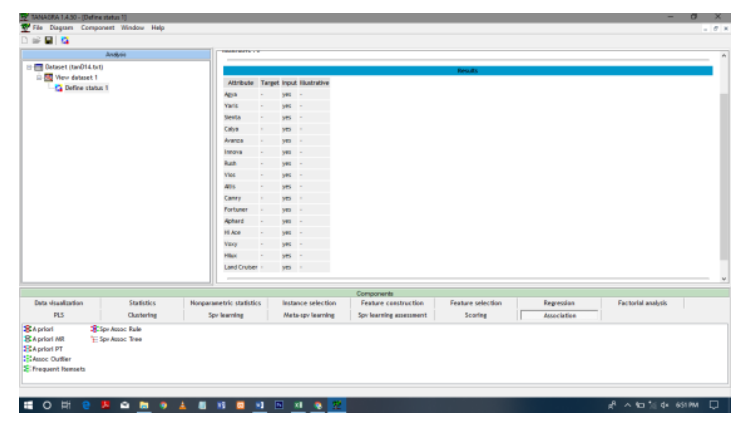

Figure 3. Output Data Results

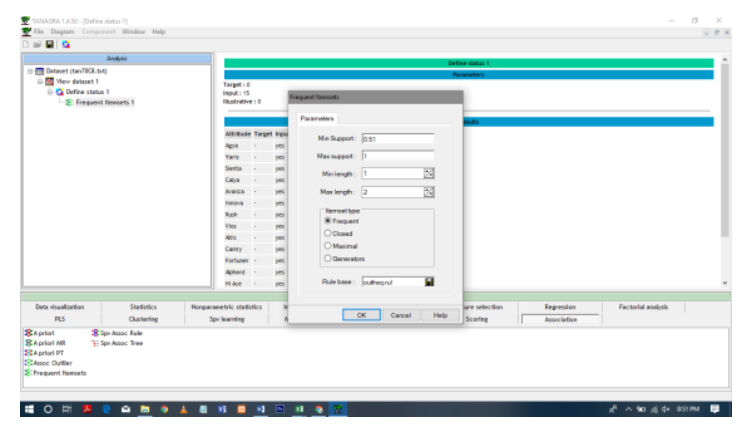

Figure 4. Itemset Search process

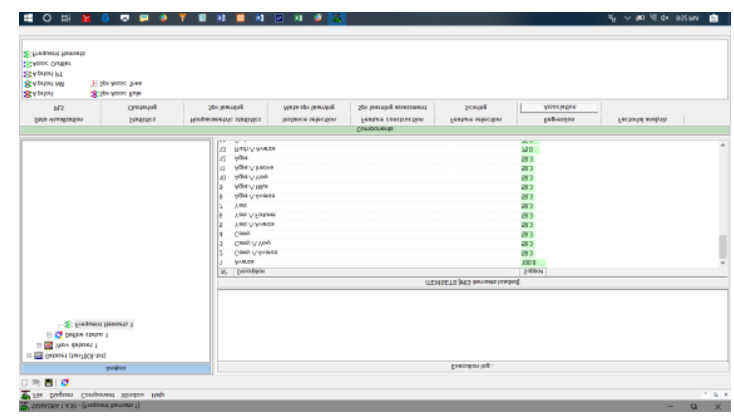

Figure 5. Support Itemset Display Results

\section{B. Confidence Algorithm}

In determining the support algorithm there are inputs, outputs and processes. The following are the results of input, output and data processing:

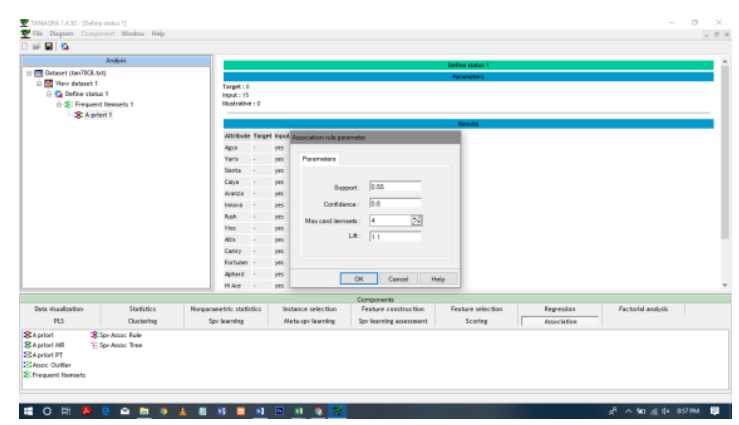

Figure 6. Input Looking for Confidence

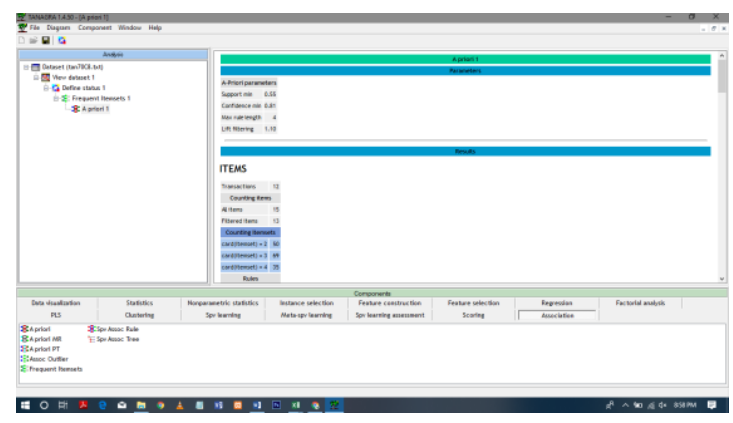

Figure 7. Results for Confidence

\section{RESUlt AND DisCuSSION}

\section{Highest Frequency Pattern Analysis}

\section{A. 1 Itemset combination}

With a minimum support value of $30 \%$, the support value of 1 item is obtained by the following formula:

$$
\operatorname{Support}(\mathrm{A}, \mathrm{B})=\frac{\sum \text { Transaction Containing A }}{\sum \text { Transaction }} * 100 \%
$$

Following is the calculation of the formation of 1 itemset:

$$
\begin{aligned}
& S(\text { Rush })=\frac{\sum \text { Rush }}{\sum 12}=\frac{\sum 4}{\sum 12} * 100 \%=33.33 \% \\
& S(\text { Vios })=\frac{\sum \text { Vios }}{\sum 12}=\frac{\sum 4}{\sum 12} * 100 \%=33.33 \% \\
& S(\text { Avanza })=\frac{\sum \text { Avanza }}{\sum 12}=\frac{\sum 8}{\sum 12} * 100 \%=66.70 \%
\end{aligned}
$$


$S($ Innova $)=\frac{\sum \text { Innova }}{\sum 12}=\frac{\sum 6}{\sum 12} * 100 \%=50.00 \%$

The support value of 1 item that has been described can be seen in the table below:

Table 2. Support 1 Itemset

\begin{tabular}{|l|c|c|}
\hline \multicolumn{1}{|c|}{ Itemset } & Support & Support (\%) \\
\hline Agya & $0 / 12$ & $0.0 \%$ \\
\hline Yaris & $1 / 12$ & $8.3 \%$ \\
\hline Sienta & $1 / 12$ & $8.3 \%$ \\
\hline Calya & $2 / 12$ & $16.7 \%$ \\
\hline Avanza & $8 / 12$ & $66.7 \%$ \\
\hline Innova & $6 / 12$ & $50.0 \%$ \\
\hline Rush & $4 / 12$ & $33.3 \%$ \\
\hline Vios & $4 / 12$ & $33.3 \%$ \\
\hline Altis & $1 / 12$ & $8.3 \%$ \\
\hline Camry & $2 / 12$ & $16.7 \%$ \\
\hline Fortuner & $1 / 12$ & $8.3 \%$ \\
\hline Alphard & $2 / 12$ & $16.7 \%$ \\
\hline Hi Ace & $1 / 12$ & $8.3 \%$ \\
\hline Voxy & $1 / 12$ & $8.3 \%$ \\
\hline Hilux & $2 / 12$ & $16.7 \%$ \\
\hline Land Cruiser & $0 / 12$ & $0.0 \%$ \\
\hline
\end{tabular}

Source : Research result (2019)

With a minimum support of $30 \%$, then the combination of 1 itemset that does not meet the minimum support will be removed in the following table:

Table 3. Minimum Support 1 Itemset

\begin{tabular}{|c|c|c|}
\hline Itemset & Support & Support(\%) \\
\hline Rush & $4 / 12$ & $33.3 \%$ \\
\hline Vios & $4 / 12$ & $33.3 \%$ \\
\hline Innova & $6 / 12$ & $50.0 \%$ \\
\hline Avanza & $8 / 12$ & $66.7 \%$ \\
\hline
\end{tabular}

Source : Research result (2019)

\section{B. 2 itemset combination}

Formation of Combinations The support values of 2 items are obtained by the following formula:

\section{$\operatorname{Support}(\mathrm{A}, \mathrm{B}) \frac{\sum \text { Transaction Containing A and B }}{\sum \text { Transaction }} * \mathbf{1 0 0} \%$}

The following is a calculation of 2 item sets:

$S($ Yaris, Innova $)=\frac{\sum \text { Yaris, } \text { Innova }}{\sum 12}=\frac{1}{12} * 100 \%$

$$
=8.33 \%
$$

$S($ Yaris, Fortuner $)=\frac{\sum \text { Yaris,Fortuner }}{\sum 12}=\frac{1}{12} * 100 \%=$ $8.33 \%$

$$
\begin{aligned}
S(\text { Sienta, Avanza }) & =\frac{\sum \text { Sienta, Avanza }}{\sum 12}=\frac{1}{12} * 100 \% \\
& =8.33 \%
\end{aligned}
$$

$S($ Sienta, Voxy $)=\frac{\sum \text { Sienta, }, \text { oxy }}{\sum 12}=\frac{1}{12} * 100 \%=8.33 \%$

$S($ Calya, Avanza $)=\frac{\sum \text { Calya, Avanza }}{\sum 12}=\frac{2}{12} * 100 \%$

$$
=16.67 \%
$$

$S($ Calya, Vios $)=\frac{\sum \text { Calya, Vios }}{\sum 12}=\frac{1}{12} * 100 \%=8.33 \%$

$S($ Avanza, Innova $)=\frac{\sum \text { Avanza, Innova }}{\sum 12}=\frac{3}{12} * 100 \%$

$$
=25.00 \%
$$

$S($ Avanza, Rush $)=\frac{\sum \text { Avanza, Rush }}{\sum 12}=\frac{2}{12} * 100 \%$

$$
=16.67 \%
$$

$S($ Avanza, Vios $)=\frac{\sum \text { Avanza, Vios }}{\sum 12}=\frac{2}{12} * 100 \%$

$$
=16.67 \%
$$

$S($ Avanza, Altis $)=\frac{\sum \text { Avanza, Altis }}{\sum 12}=\frac{1}{12} * 100 \%$

$$
=8.33 \%
$$

$S($ Avanza, Camry $)=\frac{\sum \text { Avanza, Camry }}{\sum 12}=\frac{1}{12} * 100 \%$

$$
=8.33 \%
$$


$S($ Avanza, Alphard $)=\frac{\sum \text { Avanza, Alphard }}{\sum 12}=\frac{1}{12} * 100 \%$

$$
=8.33 \%
$$

$S($ Avanza, Voxy $)=\frac{\sum \text { Avanza, } \text { Voxy }}{\sum 12}=\frac{1}{12} * 100 \%$

$$
=8.33 \%
$$

$S($ Avanza, Hilux $)=\frac{\sum \text { Avanza, Hilux }}{\sum 12}=\frac{2}{12} * 100 \%$

$$
=16.67 \%
$$

$S($ Innova, Rush $)=\frac{\sum \text { Innova, Rush }}{\sum 12}=\frac{2}{12} * 100 \%$

$$
=16.67 \%
$$

$S($ Innova, Vios $)=\frac{\sum \text { Innova, Vios }}{\sum 12}=\frac{2}{12} * 100 \%$

$$
=16.67 \%
$$

$S($ Innova, Fortuner $)=\frac{\sum \text { Innova, } \text { Fortuner }}{\sum 12}$

$$
=\frac{1}{12} * 100 \%=8.33 \%
$$

$S($ Rush, Vios $)=\frac{\sum \text { Rush, Vios }}{\sum 12}=\frac{1}{12} * 100 \%=8.33 \%$

$S($ Rush, Alphard $)=\frac{\sum \text { Rush, Alphard }}{\sum 12}=\frac{1}{12} * 100 \%$

$$
=8.33 \%
$$

$S($ Rush, Hi Ace $)=\frac{\sum \text { Rush, Hi Ace }}{\sum 12}=\frac{1}{12} * 100 \%$

$$
=8.33 \%
$$

$S($ Rush, Hilux $)=\frac{\sum \text { Rush, Hilux }}{\sum 12}=\frac{1}{12} * 100 \%=8.33 \%$

$S($ Vios, Camry $)=\frac{\sum \text { Vios, Camry }}{\sum 12}=\frac{1}{12} * 100 \%=8.33 \%$

$S($ Vios, Alphard $)=\frac{\sum \text { Vios, Alphard }}{\sum 12}=\frac{1}{12} * 100 \%$

\begin{tabular}{|c|c|c|}
\hline Item set & Support & Support (\%) \\
\hline Yaris, Innova & $1 / 12$ & $8.33 \%$ \\
\hline Yaris, Fortuner & $1 / 12$ & $8.33 \%$ \\
\hline Sienta, Avanza & $1 / 12$ & $8.33 \%$ \\
\hline Sienta, Voxy & $1 / 12$ & $8.33 \%$ \\
\hline Calya, Avanza & $2 / 12$ & $16.67 \%$ \\
\hline Calya, Vios & $1 / 12$ & $8.33 \%$ \\
\hline Avanza, Innova & $3 / 12$ & $25.00 \%$ \\
\hline Avanza, Rush & $2 / 12$ & $16.67 \%$ \\
\hline Avanza, Vios & $2 / 12$ & $16.67 \%$ \\
\hline Avanza, Altis & $1 / 12$ & $8.33 \%$ \\
\hline Avanza, Camry & $1 / 12$ & $8.33 \%$ \\
\hline Avanza, Alphard & $1 / 12$ & $8.33 \%$ \\
\hline Avanza, Voxy & $1 / 12$ & $8.33 \%$ \\
\hline Avanza, Hilux & $2 / 12$ & $16.67 \%$ \\
\hline Innova, Rush & $2 / 12$ & $16.67 \%$ \\
\hline Innova, Vios & $2 / 12$ & $16.67 \%$ \\
\hline Innova, Fortuner & $1 / 12$ & $8.33 \%$ \\
\hline Rush, Vios & $1 / 12$ & $8.33 \%$ \\
\hline Rush, Alphard & $1 / 12$ & $8.33 \%$ \\
\hline Rush, Hi Ace & $1 / 12$ & $8.33 \%$ \\
\hline Rush, Hilux & $1 / 12$ & $8.33 \%$ \\
\hline Vios, Camry & $1 / 12$ & $8.33 \%$ \\
\hline Vios, Alphard & $1 / 12$ & $8.33 \%$ \\
\hline Altis, Camry & $1 / 12$ & $8.33 \%$ \\
\hline
\end{tabular}

$$
=8.33 \%
$$

$S\left(\right.$ Altis, Camry) $=\frac{\sum \text { Altis, Camry }}{\sum 12}=\frac{1}{12} * 100 \%$

$=8.33 \%$

The support value of the 2 items that have been obtained from the description can be seen in the table below :

Table 4. Support 2 Itemset

Source : Research result (2019)

With a minimum support of $30 \%$, then the combination of 2 itemsset all of them not meeting the minimum support will be removed in the following table: 
Table 5. Minimum Support 2 Itemset

\begin{tabular}{|l|c|c|}
\hline \multicolumn{1}{|c|}{ Item set } & Support & Support (\%) \\
\hline Calya, Avanza & $2 / 12$ & $16.67 \%$ \\
\hline Avanza, Innova & $3 / 12$ & $25.00 \%$ \\
\hline Avanza, Rush & $2 / 12$ & $16.67 \%$ \\
\hline Avanza, Vios & $2 / 12$ & $16.67 \%$ \\
\hline Avanza, Hilux & $2 / 12$ & $16.67 \%$ \\
\hline Innova, Rush & $2 / 12$ & $16.67 \%$ \\
\hline Innova, Vios & $2 / 12$ & $16.67 \%$ \\
\hline
\end{tabular}

Source : Research result (2019)

\section{3 itemset combination}

Formation Combination The support value of 3 items is obtained by the following formula:

$\operatorname{Support}(\mathrm{A}, \mathrm{B}, \mathrm{C}) \frac{\sum \text { Transaction Containing A, B and C }}{\sum \text { Transaction }} * 100 \%$

The following is a calculation of 3 item sets :

$S($ Rush, Avanza, Hilux $)=\frac{\sum \text { Rush, Avanza, Hilux }}{\sum 12}=\frac{1}{12} * 100 \%$

$$
=8.33 \%
$$

The support value of the 3 items that have been obtained can be seen in the table below:

Table 6. Itemset Combination

\begin{tabular}{|c|c|c|}
\hline Itemset & Support & Support(\%) \\
\hline Rush, Avanza, Hilux & $1 / 12$ & $8.33 \%$ \\
\hline
\end{tabular}

Source : Research result (2019)

Because of the formation of 3 itemset none meet the $16 \%$ support value, then the combination of 2 itemset that meets the formation of the Association.

\section{Formation of Association Rules}

After all the high frequency patterns have been found, then the association rules are found that meet the minimum requirements for confidence by calculating the confidence of associative rules $\mathrm{A} \rightarrow$ B. Minimum Confidence $=60 \%$ Confidence value of the rules $\mathrm{A} \rightarrow \mathrm{B}$ is obtained by the following formula:

Confidence(A,B)

\section{$=\frac{\sum \text { TOTAL TRANSACTION CONTAINING A and B }}{\sum \text { TOTALTRANSACTIONA }} * 100 \%$}

The following is a calculation of 3 item sets:

$$
\begin{aligned}
C(\text { Calya }, \text { Avanza })= & \frac{\sum \text { Calya, Avanza }}{\sum \text { Calya }}=\frac{2}{2} * 100 \% \\
& =100 \%
\end{aligned}
$$

$C($ Hilux, Avanza $)=\frac{\text { Hilux, Avanza }}{\sum \text { Hilux }}=\frac{2}{2} * 100 \%=100 \%$

From the combination of 2 itemsset that has been found, it can be seen the amount of support value, and the confidence of the candidate association rules as shown in the table below:

Table 7. Support Confidence

\begin{tabular}{|l|c|c|}
\hline Rules & \multicolumn{2}{|c|}{ Confidence } \\
\hline If you buy Calya, you will buy Avanza & $2 / 2$ & $100 \%$ \\
\hline If you buy Hilux, you will buy Avanza & $2 / 2$ & $100 \%$ \\
\hline
\end{tabular}

Source : Research result (2019)

\section{Final Association Rules}

Final association rules are based on a minimum of $16 \%$ support and $60 \%$ confidence that has been determined, can be seen in the table below:

Table 8. Final Association

\begin{tabular}{|l|c|c|}
\hline \multicolumn{1}{|c|}{ Rules } & Support & Confidence \\
\hline $\begin{array}{l}\text { If you buy Calya, you will } \\
\text { buy Avanza }\end{array}$ & $16.67 \%$ & $100 \%$ \\
\hline $\begin{array}{l}\text { If you buy Hilux, you will } \\
\text { buy Avanza }\end{array}$ & $16.67 \%$ & $100 \%$ \\
\hline
\end{tabular}

Source : Research result (2019)

So based on the rules of the final association known from the transaction above, that the carrier that is most in demand by climbers is Calya, Avanza, Hilux. The results obtained can be seen in the diagram below:

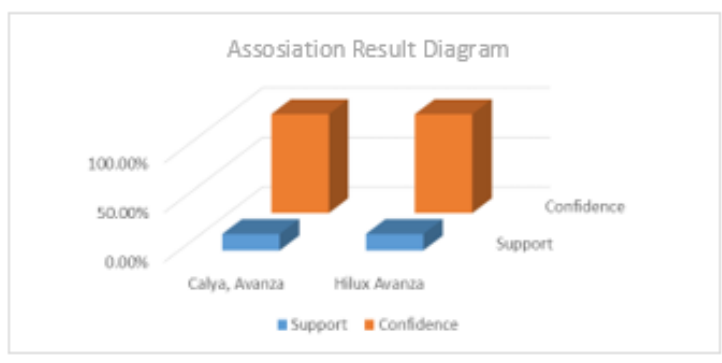

Figure 8. Diagram of the Result of Forming Final Association Rules

In this section, the researcher will explain the results of the research obtained. Researchers can also use images, tables and curves to explain the results of the study. After finishing explaining the results of the study, researchers may give a simple discussion related to the results of the research trials. 


\section{CONCluSION AND SuggeStion}

Based on the discussion that has been carried out by the author using the Apriori Algorithm and testing with the Tanagra application, we get the following conclusions::

1. Apriori Algorithm Method has been successfully applied in analyzing the brand of vehicles rented in a company based on vehicle rental data transactions that occurred in 2018 within a year. From the results of the calculation of the analysis, the author can know that the most leased vehicle brands by customers at PT. Agung Solusi Trans are Avanza (66.7\%), Innova (50.00\%), Rush $(33.33 \%)$ and Vios (33.33\%). However, Agya $(0 \%)$ and Land Cruiser $(0 \%)$ are considered by customers as brands that are less desirable or rarely rented.

2. PT. Agung Solusi Trans as a provider of brand vehicle rental services makes the calculation results with the Apriori Algorithm method to obtain very valuable information in decision makers in the company. So that PT. Agung Solusi Trans can purchase vehicles and stock with brands that are preferred by tenants and increase the inventory of those brands that will be needed in the future. In addition, in implementing and improving the right marketing strategies in order to bring benefits to the PT. Agung Solusi Trans is done by making discounts on vehicle rentals with certain brands that are rarely rented to attract tenants.

3. The results obtained from the calculation of the Apriori Algorithm analysis method, can be used as a reference for tenants in choosing a vehicle brand that suits the tenant's operational needs.

4. Apriori Algorithm testing using the Tanagra application shows that the results obtained are the same as doing Apriori Algorithm calculations manually. This can be seen through the results of calculations in the value of support and confidence.

\section{REFERENCES}

Anas, A. (2016). Analisa Algoritma Apriori Untuk Mendapatkan Pola Peminjaman Buku Perpustakaan Smpn 3 Batanghari. Jurnal Ilmiah Media SISFO, 10(2), 628-641. http://ejournal.stikomdb.ac.id/index.php/media sisfo/article/view/233/220

Badrul, M. (2015). Prediksi Hasil Pemilu Legislatif Dengan Menggunakan Algoritma K-Nearest Neighbor. Jurnal Pilar Nusa Mandiri, XI(2), 152-160.

http://ejournal.nusamandiri.ac.id/index.php/pil ar/article/view/424/374

Badrul, M. (2016). Algoritma Asosiasi Dengan Algoritma Apriori Untuk Analisa Data Penjualan. None, 12(2), 121-129. https://media.neliti.com/media/publications/22 7549-algoritma-asosiasi-dengan-algoritmaapri-f4245cc8.pdf

Halimi, I., Azhar, Y., \& Marthasari, G. I. (2019). Prediksi Harga Emas Menggunakan Univariate Convolutional Neural Network. Repositor, l(2), 105-116. https://doi.org/10.22219/repositor.v1i2.612

Handrianto, Y., \& Farhan, M. (2019). C.45 Algorithm for Classification of Causes of Landslides. SinkrOn, 4(1), 120. https://doi.org/10.33395/sinkron.v4i1.10154

Irfiani, E. (2019). Application of Apriori Algorithms to Determine Associations in Outdoor Sports Equipment Stores. SinkrOn, 3(2), 218. https://doi.org/10.33395/sinkron.v3i2.10089

Kanti, S., \& Indrajit, R. E. (2017). Implementasi Data Mining Penjualan Handphone Oppo Store Sdc Tanggerang Dengan Algoritma Appriori. Implementasi Data Mining Penjualan Handphone Oppo Store Sdc Tanggerang Dengan Algoritma Appriori, November, 1-2.

Listriani, D., Setyaningrum, A. H., \& Eka, F. (2016). Penerapan Metode Asosiasi Menggunakan Algoritma Apriori Pada Aplikasi Analisa Pola Belanja Konsumen (Studi Kasus Toko Buku Gramedia Bintaro). Jurnal Teknik Informatika, 9(2), https://doi.org/10.15408/jti.v9i2.5602

$120-127$.

Santoso, H., Hariyadi, I. P., \& Prayitno. (2016). Data Mining Analisa Pola Pembelian Produk Dengan Menggunakan Metode Algoritma Apriori. Teknik Informatika, 1, 19-24. http://ejournal.stikom-

db.ac.id/index.php/mediasisfo/article/view/233 1220

Septavia, I., Gunadhi, R. E., \& Kurniawati, R. (2014). Sistem Informasi Penyewaan Mobil Berbasis Web di GTS Mobil Bandung. 13(1999), 10-24. https://jurnal.sttgarut.ac.id/index.php/algoritm a/article/view/247/411

Sugiyono. (2015). Metode penelitian pendekatan kuantitatif, kualitatif dan R\&DNo Title. In Metode penelitian pendekatan kuantitatif, kualitatif dan $R \& D$ (pp. 80-84). Alfabeta. 